\title{
Government Innovation in Social Sciences: A Literature Review
}

\author{
Syahnaz Oriza Keumala*1, Ulung Pribadi² \\ 12 Master of Government Affairs and Administration, Universitas Muhammadiyah Yogyakarta \\ Jl. Brawijaya Kasihan Bantul, Yogyakarta, Indonesia, 55183
}

*Corresponding author: syahnazkeumala04@gmail.com

\begin{abstract}
Government innovation has become a common concept in many countries for influencing public sector reform. Government policy has also attracted attention from academia as a modern concept of governance. This study aims to understand issue innovation in government perspective. This study reviewed the literature of an article published in the social sciences through the NVivo analysis tool. This study indicates that the main issues in government innovation are public, actors, politics, policies, and institutions. This study also finds that government innovation can be used for decision making and increasing organizational capacity. In addition, it can also be used to improve democratic institutions and increase organizational. This article contributions is provide new topic concerning government innovation in the future.
\end{abstract}

Article Info :

Article history :

Received : January 17, 2021

Revised: September 14, 2021 Accepted: September 27, 2021

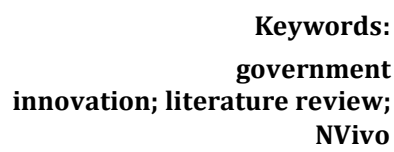

\section{INTRODUCTION}

Government innovation, research, science, and technology will form the pillars of a knowledge-based, highly productive, and competitive economy, driven by entrepreneurs in a business-friendly environment where the public and private sectors form effective partnerships (Moonesar, Stephens, Batey, \& Hughes, 2019). An aspiration of individuals, private institutions, and the government are to achieve development by generating creative ideas and introducing new products, services, and operations that increase the quality of life (Kamal, 2006). It is generally considered one of the pushers to the success of the private sector. However, the authors state that apart from being reactive rather than proactive, one of the main problems facing some government organizations in this perspective is how to successfully adopt and implement their innovations (Orange, Elliman, Kor, \& Tassabehji, 2007). In the last three decades, extensive research has been conducted to identify various factors of the success and failure of innovative technology (Arpaci, 2010). 
The government innovation early in development for more advanced regions, while developed countries have exploited the power of the Internet to enable public services successfully, developing countries are relatively slow in developing egovernment that succeeded (Wei \& Liu, 2015). In addition, the scholars explained the role of government innovation in competition among companies gradually depending on the capacity of companies to continue to be innovative in a cost-efficient manner against the background of economic globalization, rapid technological development, and industrial convergence (Deng, Lu, Hong, Chen, \& Yang, 2019).

The innovation movement in one country can increase national competitiveness in several Asian countries such as Japan, Korea, China, and Taiwan (Mok, Welch, \& Kang, 2020). Government innovation from the local perspective can be used to solve public problems (Brandsen, Steen, \& Verschuere, 2018) (Roziqin \& Fajrina, 2021). According to (Mergel, 2018), government innovation can provide information and knowledge as a policy instrument. In addition, government transformation through innovation is expected to improve government performance, including more accessible access to public information, greater citizen participation in policy decision-making, costeffectiveness, responsiveness, and accountability (Kim, 2008).

Furthermore, an expert researched the role of government in creating the Springfield Armory as a link in the innovation ecosystem (Ford \& Yoho, 2020). Lastly, a scholar describes educational governance and innovation: Technology as an objective and means of governance (Cifuentes, 2015). However, scholars rarely make a map of the government innovation literature thinking. A scholar charted in detail what issues related to the theme of government innovation; hence, this article attempts to fill this gap by explaining the innovation dimension in the government's written by social science scholars. This study addresses the following questions: (1) what are the main issues and derivative issues of innovation the government late in the journal Science (2) What is the contribution of the central issues to development innovation theory of government and the practical needs of policymakers? The study conducted a systematic literature review of articles on innovation the government in social science journals.

\section{METHOD}

All journal articles previously published on government innovation in the social sciences can be found in the Scopus Database. This archive contains all of these articles from previous years, from inception to 2020. This study takes an entire sample of all publication years to minimize bias from a limited sample size. Therefore, this study obtained a representative and accurate sample. There are five steps for conducting a systematic literature review according to scholars (Wang, Hu, \& Yang, 2019) : (1) compiling and formulating subjects; (2) literature search; (3) data collection and evaluation; (4) data analysis and interpretation; and (5) present the results and propose future research. This research uses the Scopus database for the articles to be obtained. The search settings in the database are: Government innovation title; Access types are open access and others; Years until 2020 from the earliest possible date; All authors' names; the subject area is a social science; Types of documents are articles; The publication stage is final; Source titles are all social science journals; The keywords are government innovation; Countries/regions are all countries; The source type is a journal, and Language is English. It has produced 30 journal articles. The NVivo 12 Plus software

171 | Journal of Local Government Issues (LOGOS), 4 (2), September 2021, pp 170184

ISSN : 2620-8091 print | 2620-3812 online 
application was used in this study to analyze, visualize, and categorize data. NVivo is useful as analysis software that helps catalog elements of textual documents and scan data for terms and phrases (Sotiriadou, Brouwers, \& Le, 2014). This study uses data elements NVivo to an index journal article by searching terms related to government innovation.

\section{RESULTS AND DISCUSSION}

A description and interpretation of the results are provided in this section. The description includes the year of publication, journal title, and citations per author. The analysis of findings contains the main issues of government innovation, public issues, political issues, institutional issues, actor issues, and policy issues.

\section{The Years Of Publication}

Figure 1 shows the trend that the number of publications related to government innovation can be seen in the figure in 2005, there are two issues related to government innovation, and then in 2006 to 2013, publications related to government innovation became only one issue. Published in 2014,it increased to 2 issues related to government innovation. In 2015 the number of articles discussing government innovation increased to 5 issues; in 2017, there was only one issue discussing government innovation; in 2018, it increased to 4 issues; in 2019, there were six issues. Finally, in 2020 the articles discussing government innovation were decreased to 4 issues.

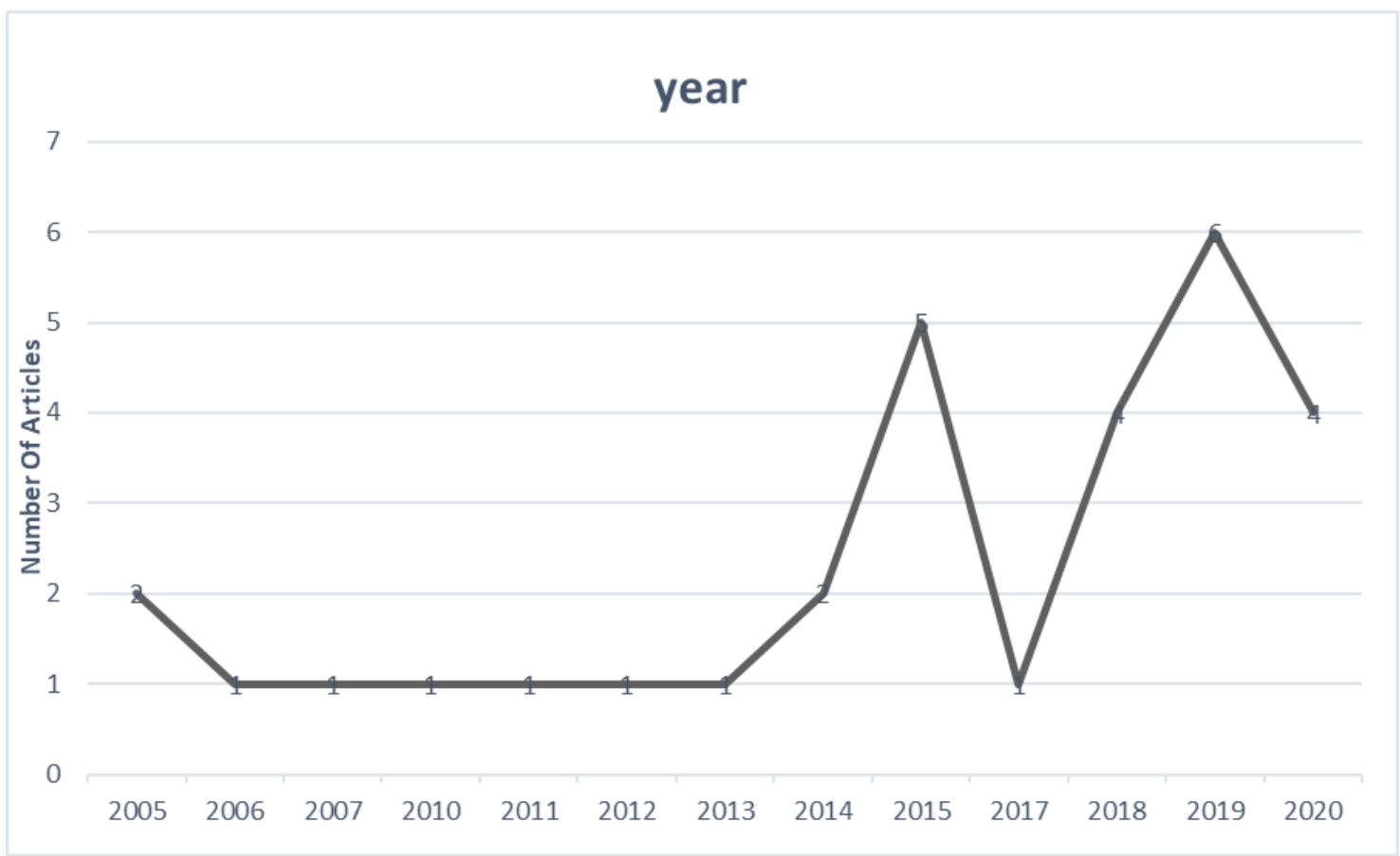

Figure 1. Evolution over time of posts about network governance

\section{Journal Titles}

In the field of social science, all journal articles on government innovation have been written. In the Scopus database, this article has been indexed. The names of journals

172 | Journal of Local Government Issues (LOGOS), 4 (2), September 2021, pp 170184

ISSN : 2620-8091 print | 2620-3812 online 
containing at least two articles on governance innovation are listed in table 1 . The four journals with the highest number of articles are the Journal of Corporate Information Management which discusses The American Review of Public Administration, the Journal of Public Sector Management, and the Journal of Institutional Economics.

Table 1. Analyzed Journals

\begin{tabular}{llcc}
\hline No & Journal & $\begin{array}{l}\text { No. of } \\
\text { articles }\end{array}$ & \% \\
\hline 1 & Company information management journal & 3 & 0,1 \\
2 & The American Review of Public Administration & 3 & 0,1 \\
3 & Journal Management sector Publics & 3 & 0,1 \\
4 & Journal of Institutional Economics & 3 & 0,1 \\
\hline \multicolumn{2}{c}{ Source: Researcher, 2020 }
\end{tabular}

Figure 2 shows the numerical citation per author. In government innovation, the number of citations per author's statistic can reflect the author's academic influence. Here are the 21 authors with the highest total citations. They are M.M. Kamal, Journal of Company Information Management (2006, Brunel University London) with 362 quotes; Kimberly L. Nelson and James H. Svara, The American Review of Public Administration (2012, Arizona State University) with 122 quotes; Jiuchang Wei Yang Liu (2015, University of Science and Technology of China) with 40 quotes; Jason Potts (2018, School of Economics, Finance and Marketing, RMIT University, Melbourne, Australia) with 31 quotes; Graham Orange (2007, Leeds Metropolitan University, Leeds, UK) with 28 quotes; Sohee park (2018 School of Business Administration, Inje University, Gimhae, South Korea) with 26 quotes; Ibrahim Arpaci (2010, Department of Information Systems, Informatics Institute, Middle East Technical University, Ankara, Turkey) with 25 quotes; Patarapong Intarakumnerd (2005, Additional services and information for Science Technology \& Society can be found) with 25 quotes; Chun yang (2015, Department of Geography, Hong Kong Baptist University, Hong Kong) with 24 quotes; Moeketsi Letseka (2005, Senior Research Specialist, Research Programme: Human Resources Development, Human Sciences Research Council) with 17 quotes; José-Valeriano FríasAceituno, Lázaro Rodríguez-Aríza\& María-Isabel González-Bravo (2013) with 16 quotes; Liang and Langbein (2018) with 15 quotes; Jay Na Lim (2014, Institute for Industrial Production (IIP), Karlsruhe Institute of Technology (KIT), Karlsruhe, Germany) with 10 quotes; Kimberly L. Nelson, Curtis H. Wood and Gerald T. Gabris (2011, Kimberly L. Nelson, Ph.D., Curtis H. Wood, Ph.D., and Gerald T. Gabris, Ph.D., are an Assistant Professor, an Associate Professor, and a Distinguished Teaching Professor, respectively, Division of Public Administration, Northern Illinois University. Dr. Nelson's teaching and research interests are in local government management, innovation, and form of government. Dr. Wood's teaching and research interests are in public management, ethics, and new governance. Dr. Gabris's teaching and research interests include human resources management and organizational behavior) with 8 quotes; Taewoo Nam (2018, Graduate School of Governance, Sungkyunkwan University, Seoul, The Republic of Korea) with 8 quotes; Klas Palm, Johan Lilja and Håkan Wiklund (2015, Department of Quality Technology and Management, Mid Sweden University, Knivsta, Sweden) with 8 quotes;

173 | Journal of Local Government Issues (LOGOS), 4 (2), September 2021, pp 170184

ISSN : 2620-8091 print | 2620-3812 online 
Gary Cifuentes (2015, University of los Andes, Colombia) with 8 quotes; Ping Deng, Hao Lu, Jin Hong, Qiong Chen and Yang Yang (2019, School of Management, University of Science and Technology of China, Hefei, China) with 6 quotes; Siying Yang and Zheng Li (2020, Centre for China Public Sector Economy Research, Jilin University, Changchun, China and Economics School, Jilin University, Changchun, China, and School of Finance and International Business School, Zhejiang Gongshang University, Hangzhou, China) with 4 quotes; Donghun Yoon (2018, Seoul Center, Korea Basic Science Institute, Seoul, South Korea) with 4 quotes; Jiuchang Wei and Yang Liu (2015 School of Management, University of Science and Technology of China, Hefei, China) with 3 quotes; Aliza A. Omar And Avvari V. Mohan (2017, Faculty of Management, Multimedia University, Cyberjaya 63100, Selangor, Malaysia) with 2 quotes; Immanuel Azaad Moonesar, Melodena Stephens, Mark Batey and David J. Hughes (2019, Academy of International Business Middle East North Africa Chapter Association and Mohammed Bin Rashid School of Government) with 1 quotes; Margaret M. Pearson (2019) with 1 quotes; Ying Wang, Hanhui Hu and Xiaolei Yang (2019, School of Economics and Management, Southeast University, Nanjing, China) no citation yet.

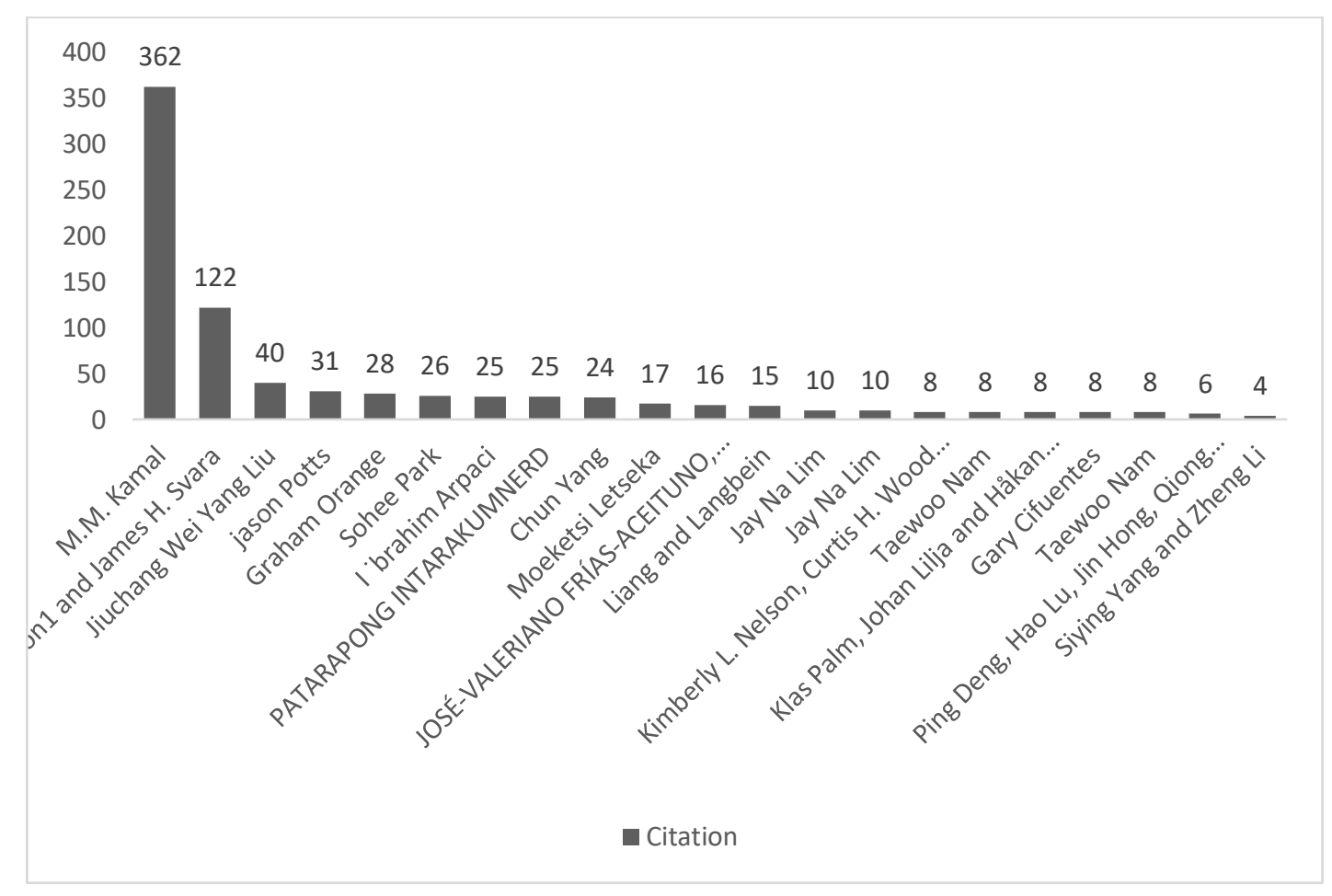

Figure 2. Number of Citations Per Author (top 21 authors)

\section{The Main Issues of Governance Innovation}

This study uses NVivo 12 plus to demonstrate keyword co-occurrences and provide an overview of the significant problems of government innovation discussed in social science journals. In the literature review method, scholars use NVivo to assist research. The most common techniques for data analysis at NVivo. NVivo devises a coding 
scheme. NVivo processes data and builds coding systems and codes through automated coding tools (Brandão \& Miguez, 2017). NVivo is the optimal collection of literature analysis methods for qualitative analysis software packages (Di Gregorio, 2000). NVivo allows knowledge to be handled and organized by scholars and enables them to more comfortably interpret information, define patterns, gain insights, and draw conclusions. Critically, NVivo enables investigators to encode all knowledge and construct themes, groups, or nodes (Sotiriadou et al., 2014). The innovation image node is the keyword in Figure 3, while the link indicates the node relationship. In the figure, the numbers represent the percentage of the frequency with which they occur together. Figure 3 emphasizes that government innovation also occurs with five main keywords governance, innovation, technology, research, and society. It is the primary term of government innovation.

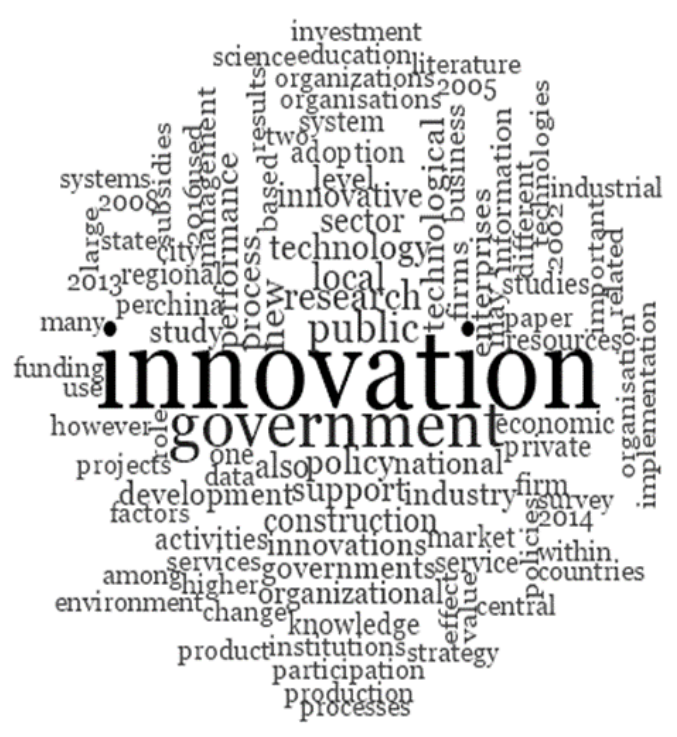

Figure 3. Main Keywords of Government Innovation

\section{Issue 1: Government Issues}

Figure 4 shows the percentage frequency of occurrence of the word government in other words. The word government contract has a high percentage of occurrence frequency equal to the other four words: government expenditure, government demand, government entities, and government information. These findings indicate that the word government is very closely related to the other four words. Meanwhile, the word government impact has a lower percentage of occurrence frequency, in other words, namely government departments, government decisions, government data, and government culture. 


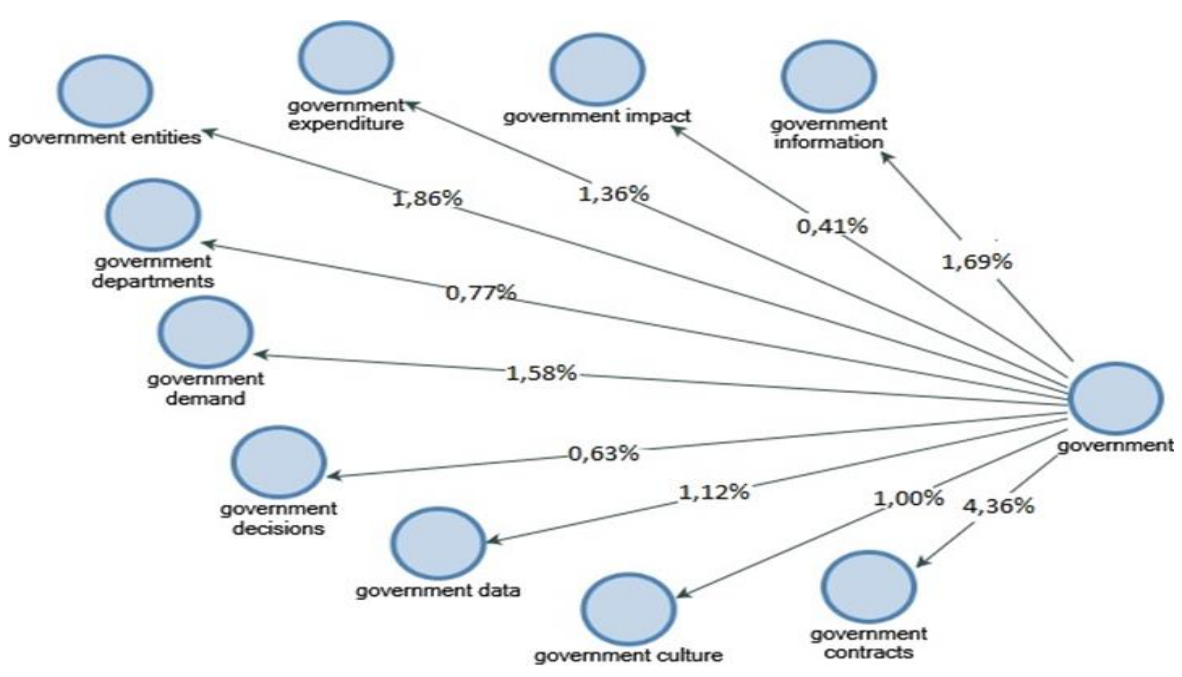

Figure 4. Government Issues

According to scholars, Innovation and creativity in the context of the UAE are defined as the aspirations of individuals, private and government institutions to achieve development by generating creative ideas and introducing new products, services, and operations that improve the overall quality of life (Wang et al., 2019), while according to other scholars, innovation is one of the most critical driving factors for industrial transformation, structural improvement, and sustainable economic development. Competition across countries will be determined by competition for innovation across time dimensions. The government's policy to encourage innovation and development technology stimulates certain companies, such as small and medium enterprises (SMEs) and specific industries. At the same time, certain industries may be expected to be more innovative than others (Dolfsma \& Seo, 2013). Therefore, all countries worldwide are struggling to build innovative ecological systems to increase the power of appropriate national innovation (Yang, Li, \& Li, 2020).

Other scholars explain the relationship of innovation in companies. Competition among companies gradually depends on the capacity of the company to continue to innovate cost-effectively against the background of the globalization economy, rapid technological developments, and industrial convergence (Potts, 2018). Government support for corporate research and development (R\&D) is the main incentive to encourage innovation in company performance (Chonka, 2019).

Proposition one: Successful governance innovation is determined at least by models of government expenditure, government demand, government entities, and government information.

\section{Issue 2: Issue of Innovation}

The percentage of the frequency of occurrence of the word innovation, in other words, is shown in Figure 5. Together with the other three terms, the term innovation has a high percentage of occurrences, namely conceptual innovation and current innovation. These results reveal that the words innovation are closely related to the other three words. The word innovation has a lower percentage of the number of occurrences together. These words affect city innovation, administrative innovations, collaborative 
innovation, communication innovation, effecting innovation; generally, innovation constrains innovation and practical innovation.

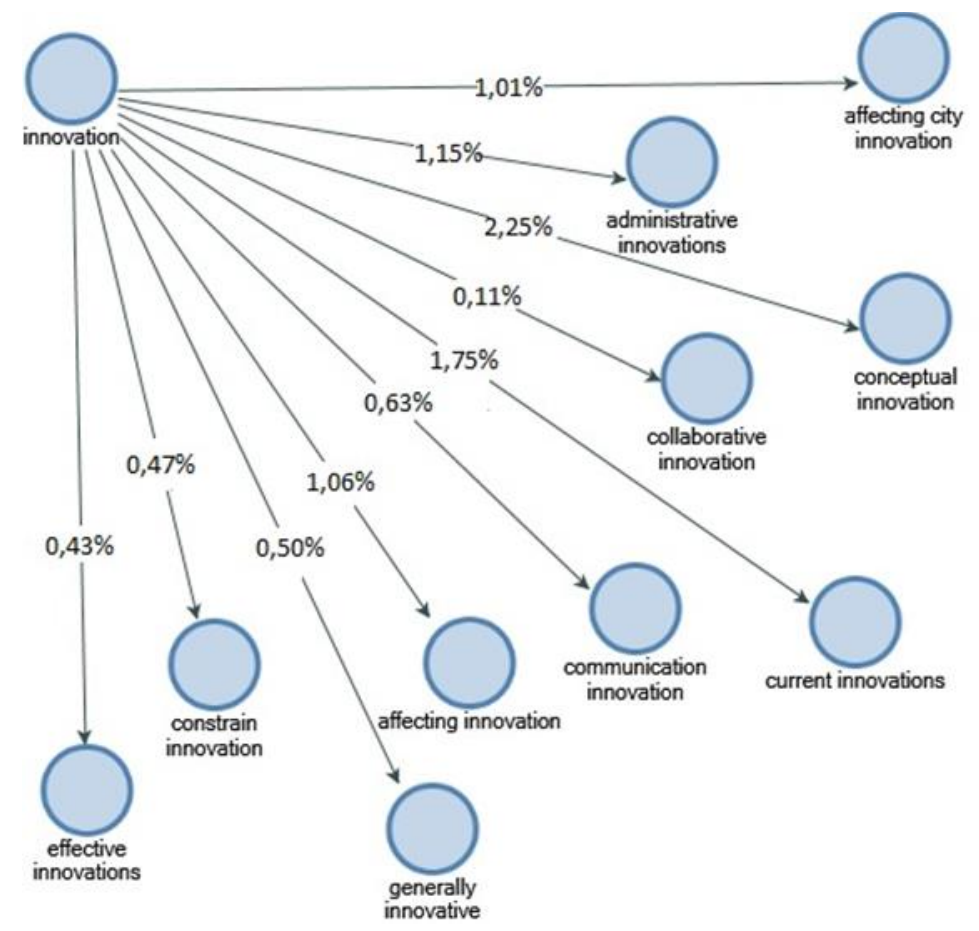

Figure 5: Innovation Issues

According to scholars, open innovation is a place where organizations seek external ideas and technologies used in their own business and share internal ideas and technologies that have not been or are not used so far with other individuals to use in their business (Omar, Mohan, \& Zhao, 2017). In the private sector, innovation is associated with apparent behavior. Therefore innovation requires imagination and courage. However, in the private sector, innovation is often financially rewarded. So people in the private sector tend to value promotion and investing (Kamarck, 2004). The public sector has traditionally been a monopoly provider of various goods and services; people in the public sector have little incentive to engage in or invest in innovation (Hamed Hilal \& Said, 2013). Lichtenthaler and Lichtenthaler's (2009) article introduces open innovation in which different knowledge management-based methods are built into a single framework for knowledge exploration, retention, and exploitation within and beyond firm boundaries.

As for countries in southern Africa, the need to encourage and support partnerships between higher education institutions (HEI), industry, and science, engineering, and technology (SET) institutions cannot be overemphasized. Innovation policy is only considered at the core of the initiative as an improvement in economic policy. In South Africa, it is only 'symbolic,' not as an industry (Letseka, 2005).

Meanwhile, other scholars specifically for the construction industry encourage construction innovation to enter Germany through programs such as "Direct Promotion of Research in Thematic Program (Lim, 2014). Europe will next target technology, 
regional and urban innovation and reopen discussions of the old relationship between innovation and space when calling smart cities an integrative concept for interdisciplinary knowledge. Creation and capacity building (Etzkowitz \& Zhou, 2017).

Some scholars discuss that innovation in education has become one of the main topics on many countries' political agendas (Cifuentes, 2015). To shape the added value of innovation in education: innovation education can improve learning outcomes and education quality; innovation helps to increase equity (access) and equity (in learning outcomes); and innovation stimulates and enhances the efficient delivery of education as a public service (Cifuentes, 2015).

Proposition two: government innovation depends on ongoing innovation carried out by the government, while private companies improve their performance in realizing the innovation.

\section{Issue 3: Technology Issues}

Figure 6 shows the percentage frequency of occurrence of the term technology with other terms. The word technology has a high percentage of occurrence frequency and three other terms, namely standard technology, environmental technologies, and technological competitiveness. Urban, political processes, and political communication; These findings indicate that technology has a meaning that is very closely related to the other three terms. Meanwhile, in other words, said communications technology introduced technology, integrating technology, instructional technologies, material technology, and technological compatibility.

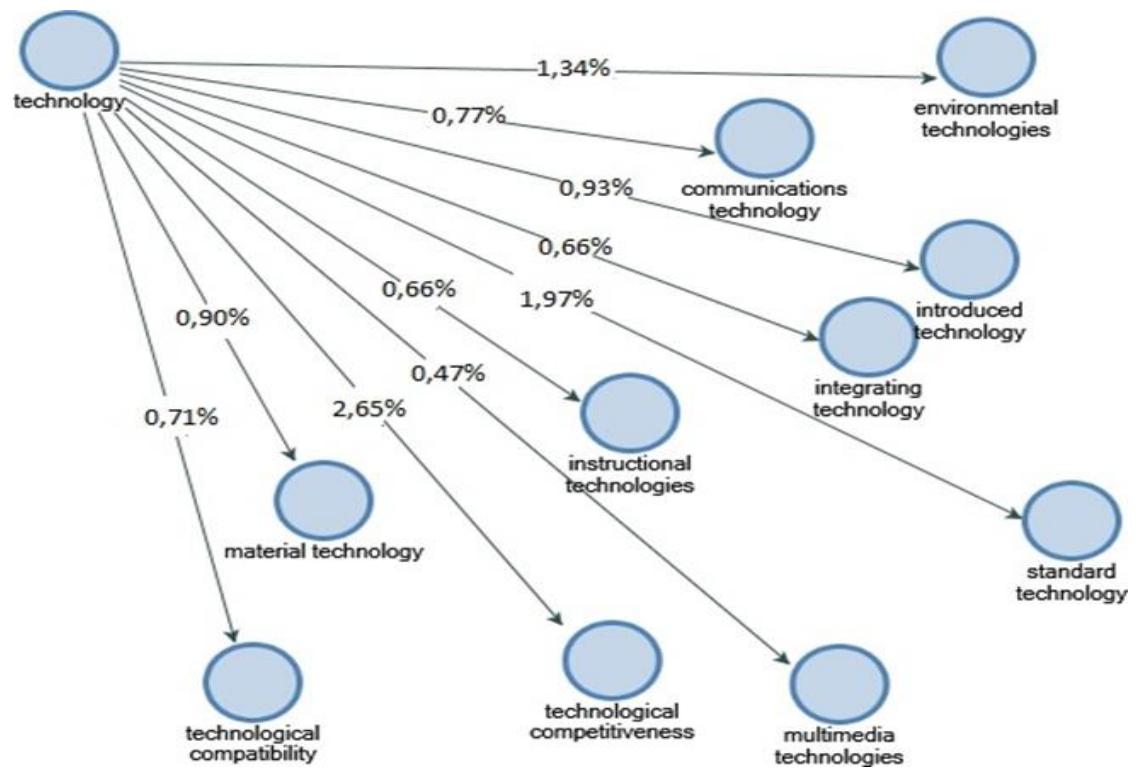

Figure 6: Technology issues

According to technology scholars who can assist government innovation based on the assumption that educational change will emerge through intensive use of technology, the role of information and communication technology (ICT) has become a common feature in the education policy agenda (Kozma, 2008). IT innovation focuses on identifying from the operational practice lab. This dimension has a risk that focuses on identifying critical barriers and problems and ways to overcome them through various

178 | Journal of Local Government Issues (LOGOS), 4 (2), September 2021, pp 170184

ISSN : 2620-8091 print | 2620-3812 online 
points in implementing the innovation strategy (Scherlis \& Eisenberg, 2003). Defines egovernment as the use of all forms of information and communication technology (ICT) by governments and their agents for improved operations, delivery of information and public services, citizen engagement and public participation, and governance processes. E-government can be seen as a form of modernization. It is primarily seen as a generator for the change process among government administrations with the potential for significant performance improvements in the public sector (Arpaci, 2010).

Proposition three: Technology assists governments in making sustainable innovations that can facilitate performance.

\section{Issue 4: General Issues}

Figure 7 shows the percentage frequency of occurrence of the term technology with other terms. The word technology has a high percentage of occurrence frequency and three other terms, namely standard technology, environmental technologies, and technological competitiveness. These findings indicate that technology has a meaning that is very closely related to the other three terms. Meanwhile, in other words, communications technology, introduced technology, integrating technology, instructional technologies, material technology, and technological compatibility have a lower percentage.

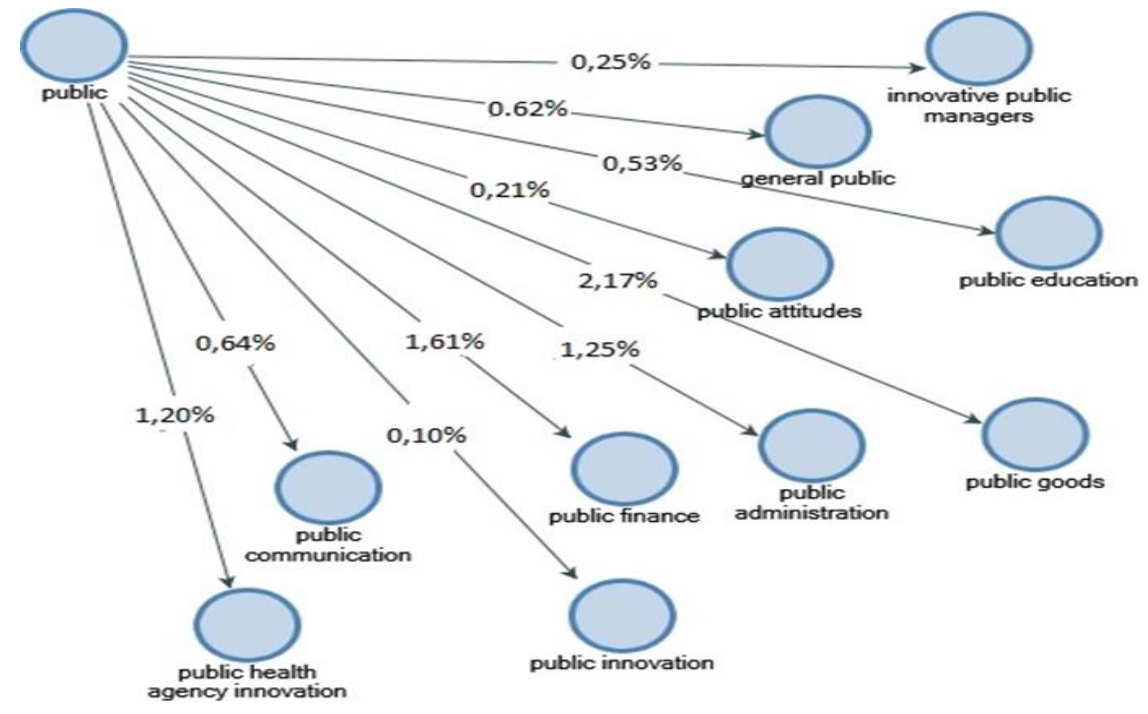

Figure 7: General Issues

According to scholars, the general issues in government in realizing innovation lack understanding of innovation activities and their economic impact, and the guidelines are designed only for innovation in the business sector. Little is known about the public sector's innovation process, thus leaving much room for exploration of innovation in such types of contexts (Orange et al., 2007). The scholars researching Leadership in the United Arab Emirates (UEA) drive innovation in systems, processes, and organizational structures.

The President and Prime Minister of the UAE and Dubai launched the UAE National Innovation Strategy to make the UAE one of the most innovative countries in the world in the next seven years. Their foresight is framed in the UAE Vision 2021: 
Innovation, research, science, and technology will form the pillars of a knowledge-based, highly productive, and competitive economy, driven by entrepreneurs in a public and private sector friendly business environment forming effective partnerships (Moonesar et al., 2019). This strategic focus is implemented and promoted through awareness programs, workshops, seminars, conferences, forums, and debates. Encouraging this innovation is one of the many vital dimensions in government to improve the existing system. To increase citizens' expectations, old government and public services models need to be changed or undergo a process of creative destruction to create new ideas and public value by utilizing the latest available knowledge and technology efficiently and effectively. With the increasing focus on this topic, with government entities creating 'innovation departments,' there is a need to audit and explore the meanings, implications, and barriers to making Dubai's government sector innovative and creative (Moonesar et al., 2019). Public services, developing countries have been relatively slow in developing successful e-Govt strategies (Stoltzfus, 2004) (Weerakkody \& Reddick, 2012).

Proposition Four: Common issues that occur in society make the government innovate to make it easier for society and create a stable community economy.

\section{Issue 5: Policy Issues}

Figure 8 shows the percentage occurrence of policy terms with other terms. The word policy has a high occurrence frequency, along with three other terms, namely innovation policy, government policies, and industrial policy. These findings indicate that policy has a meaning that is very closely related to the other three terms. Meanwhile, in other words, the words development policies, aggressive policies, fiscal policies, education policies, economic policies, policy analyzes, and investment policies have a percentage below the three words mentioned above.

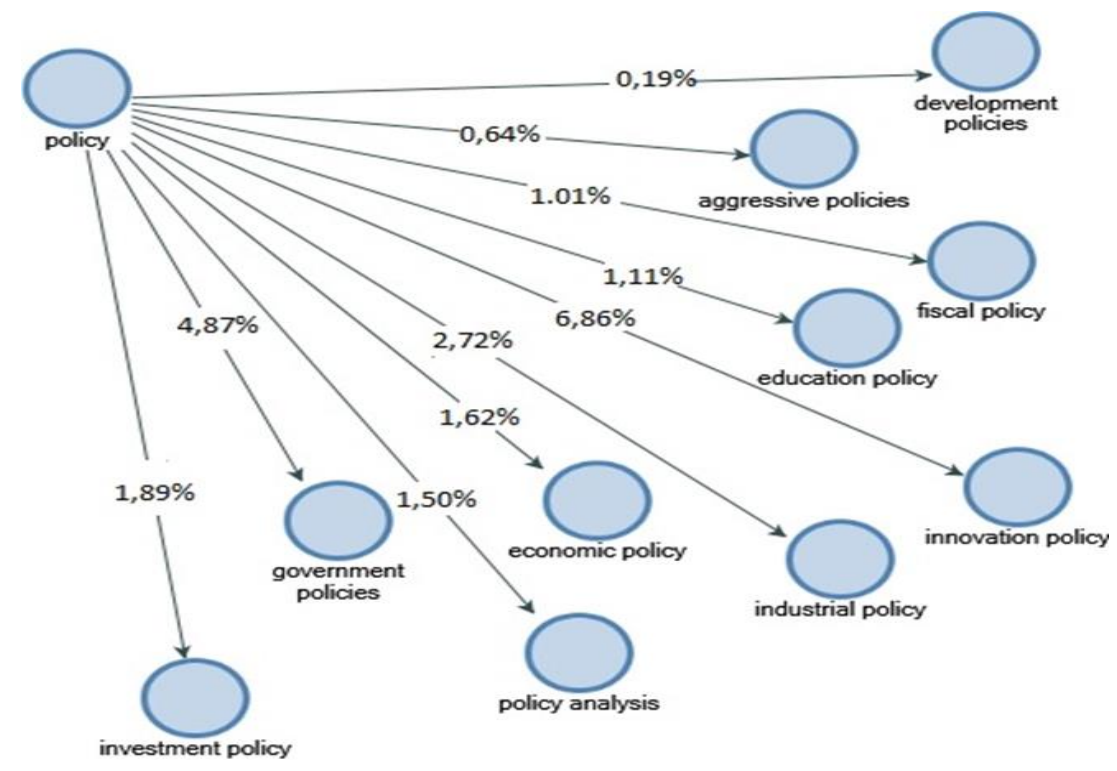

Figure 8: Policy Issues

According to scholars, government innovation has a relationship with policy, policy education, policy economics, and policy analysis. Innovation policies are considered at the heart of economic growth and global competitiveness, and countries

180 | Journal of Local Government Issues (LOGOS), 4 (2), September 2021, pp 170184

ISSN : 2620-8091 print | 2620-3812 online 
invest large sums of money in exerting influence on innovation. Higher education institutions that collaborate with industry are expected to play a vital role in supporting the national innovation system and developing the nation's global competitiveness (Letseka, 2005). Variables traditionally associated with general state innovation, such as state wealth, urbanization, and population education, were not significant predictors of early e-government innovation in 2000 , measured by online services and the overall scope of implementation (Etzkowitz \& Zhou, 2017). For example, the US's small business innovation research program provides grants to research and small companies to develop new technologies in business (Tolbert, Mossberger, \& McNeal, 2008).

AHP's comprehensive evaluation To decide whether to carry out government business or not, it is necessary to conduct a comprehensive evaluation of the economic, policy, and technical validity (Yoon, 2018). A questionnaire survey was conducted on a professional group (30 specialists) for preliminary policy research, from feasibility studies to government R\&D innovation strategies. Some Professional groups consist of 10 professors, ten scientists, and ten engineers. Moreover, fourteen variables were selected to analyze the influence factor in the feasibility study by having a variable consisting of seven steps for the interval scale. The factor method is effective for extracting and analyzing the common core factors. Also, reliability verification is required for the extracted factors. The reliable factors obtained from reliability verification can be used in various types of analysis and for effective policymaking (Yoon, 2018).

Meanwhile, another scholarly article states that in Japan, Korea, and Taiwan, S\&T elements are not part of broader economic policy, namely, industrial policy, investment policy and trade policy, and, to a lesser extent, educational policy (Intarakumnerd, 2005). China, which operates in the context of China's political and industrial policy systems, does and does not develop innovative ecosystems for companies (Pearson, 2019).

\section{CONCLUSION}

Governance innovation has been discussed from a social science perspective by several scholars. This study contributes to the broadening of the debates and viewpoints of these social science scholars. The literature review of these articles on government innovation provides an opportunity to consider state of the art and define courses of study. Thirty journal articles published in the Scopus database were reviewed in this study. This study examines five government issues: public issues, innovation issues, technology issues, policy issues, and general issues. There are also five prepositions formed in this review. First, practical government innovation is determined by public policy models, government policies in making innovations, and public management. Second, government innovation in policymaking and implementation depends on technology, policy, and society. Third, government innovation enforcement must be considered in technological and policy processes, especially in the general urban population. Fourth, government innovation is an effective means of policy decisionmaking, implementation, and assessment in several fields and contexts. Finally, creating government innovation requires a political system to be reorganized to create democratic institutions to deal with problems of joint decision-making.

In mapping the concept of government innovation, this research provides a new theoretical contribution. This study also provides the following practical steps: (1)

181 | Journal of Local Government Issues (LOGOS), 4 (2), September 2021, pp 170184

ISSN : 2620-8091 print | 2620-3812 online 
government innovation can be used by private companies in decision-making and implementation to expand capacity; (2) elected officials can take advantage of government innovation experiences to improve democratic institutions; and (3) awareness of government innovations can be used by appointed officials to increase efficiency.

\section{REFERENCES}

Arpaci, I. (2010). E-Government and Technological Innovation in Turkey: Case Studies on Governmental Organizations. Transforming Government: People, Process and Policy, 4(1), 37-53. https://doi.org/10.1108/17506161011028795

Brandão, C., \& Miguez, J. (2017). Using NVivo to Assess a Program of Goal-Corrected Empathic Attunement Skills: a Case Study in the Context of Higher Education. Universal Access in the Information Society, 16(4), 863-876. https://doi.org/10.1007/s10209-016-0476-x

Brandsen, T., Steen, T., \& Verschuere, B. (2018). Co-Creation and Co-Production in Public Services. Urgent issues in Practice and Research Co-Production and Co-Creation (pp. 3-8): Routledge.

Chonka, P. (2019). News Media and Political Contestation in the Somali Territories: Defining the Parameters of A Transnational Digital Public. Journal of Eastern $\begin{array}{lll}\text { African } \quad \text { Studies, 13(1), } & \text { 140-157. }\end{array}$ https://doi.org/10.1080/17531055.2018.1548210

Cifuentes, G. (2015). Educational Governance and Innovation: Technology as End and Means of Government. Policy Futures in Education, 14(2), 286-299. https://doi.org/10.1177\%2F1478210315622916

Deng, P., Lu, H., Hong, J., Chen, Q., \& Yang, Y. (2019). Government R\&D Subsidies, Intellectual Property Rights Protection and Innovation. Chinese Management Studies, 13(6). https://doi.org/10.1108/CMS-02-2018-0422

Di Gregorio, S. (2000). Using Nvivo for Your Literature Review. Paper presented at the meeting of the strategies in qualitative research: 1 Issues and results from the analysis using QSR NVivo and NUD* IST. https://cmapspublic3.ihmc.us/rid=1GXNJD0W2-HGB31R-

DGD/literature_review_\%20cdoing\%20_nvivo.pdf

Dolfsma, W., \& Seo, D. (2013). Government Policy and Technological Innovation-A $\begin{array}{llll}\text { Suggested Typology. } & \text { Technovation, }\end{array}$ https://doi.org/10.1016/j.technovation.2013.03.011

Etzkowitz, H., \& Zhou, C. (2017). The Triple Helix: University-Industry-Government Innovation and Entrepreneurship: Routledge.

Ford, R. C., \& Yoho, K. D. (2020). The Government's Role in Creating an Innovation Ecosystem: the Springfield Armory as Hub in the Connecticut River Valley. Journal of Management History, 26(4). http://dx.doi.org/10.1108/JMH-02-2020-0016

Hamed Hilal, A., \& Said, A. (2013). Using Nvivo for Qualitative Data Analysis. Int Interdiscip JEduc, 2(2), 181-186. https://platform.almanhal.com/Reader/Article/42766

Intarakumnerd, P. (2005). Government Mediation and Transformation of Thailand's National Innovation System. Science, Technology and Society, 10(1), 87-104. https://doi.org/10.1177\%2F097172180401000105

182 | Journal of Local Government Issues (LOGOS), 4 (2), September 2021, pp 170184

ISSN : 2620-8091 print | 2620-3812 online 
Kamal, M. M. (2006). IT Innovation Adoption in the Government Sector: Identifying the Critical Success Factors. Journal of Enterprise Information Management, 19(2), 192-222. http://dx.doi.org/10.1108/17410390610645085

Kamarck, E. (2004). Government Innovation Around the World. Available at SSRN 517666. https://dx.doi.org/10.2139/ssrn.517666

Kim, S. (2008). Local Electronic Government Leadership and Innovation: South Korean Experience. Asia Pacific Journal of Public Administration, 30(2), 165-192. https://doi.org/10.1080/23276665.2008.10779349

Kozma, R. B. (2008). Comparative analysis of policies for ICT in education. International handbook of information technology in primary and secondary education, 20, 10831096. https://doi.org/10.1007/978-0-387-73315-9_68

Letseka, M. (2005). Government Incentivization of Partnerships in South Africa: An Audit of THRIP and the Innovation Fund. Industry and Higher Education, 19(2), 161-168. https://doi.org/10.5367\%2F0000000053729798

Lim, J. N. (2014). The Government as Marketer of Innovation. Engineering, Construction and Architectural Management, 21(5), 551-570. https://doi.org/10.1108/ECAM04-2011-0042

Mergel, I. (2018). Open Innovation in the Public Sector: Drivers and Barriers for the Adoption of Challenge. gov. Public Management Review, 20(5), 726-745. https://doi.org/10.1080/14719037.2017.1320044

Mok, K.-H., Welch, A., \& Kang, Y. (2020). Government Innovation Policy and Higher Education: the Case of Shenzhen, China. Journal of Higher Education Policy and Management, 42(2), 194-212. https://doi.org/10.1080/1360080X.2019.1701851

Moonesar, I. A., Stephens, M., Batey, M., \& Hughes, D. J. (2019). Government Innovation and Creativity: A Case of Dubai Future Governments: Future Governments (Actions and Insights - Middle East North Africa, Vol. 7), Emerald Publishing Limited, Bingley, pp. 135-155 https://doi.org/10.1108/S2048-757620190000007007

Omar, A. A., Mohan, A. V., \& Zhao, X. (2017). Can Government Policies Drive Open Innovation Type Platforms? Ideas From the MSC Malaysia Flagship Applications. Science, Technology and Society, 22(3), 490-505. https://doi.org/10.1177\%2F0971721817724315

Orange, G., Elliman, T., Kor, A. L., \& Tassabehji, R. (2007). Local Government and Social or Innovation Value. Transforming Government: People, Process and Policy, 1(3), 242252. https://doi.org/10.1108/17506160710778086

Pearson, M. M. (2019). Local Government and Firm Innovation in China's Clean Energy Sector Policy, regulation and innovation in China's electricity and telecom industries (pp. 96-133): Cambridge University Press Cambridge. https://doi.org/10.1017/9781108645997.003

Potts, J. (2018). Governing the Innovation Commons. Journal of Institutional Economics, 14(6), 1025-1047. https://doi.org/10.1017/S1744137417000479

Roziqin, A., \& Fajrina, A. N. (2021). Understanding Public Sector Innovation from A Local Perspective: Contra War (Contraceptive for Women at Risk) Innovation Study in Malang Regency. Jurnal Borneo Administrator, 17(2), 205-222. https://doi.org/https://doi.org/10.24258/jba.v17i2.803

183 | Journal of Local Government Issues (LOGOS), 4 (2), September 2021, pp 170 184

ISSN : 2620-8091 print | 2620-3812 online 
Scherlis, W. L., \& Eisenberg, J. (2003). IT Research, Innovation, and E-Government. Communications of the ACM, 46(1), 67-68. https://doi.org/10.1145/602421.602455

Sotiriadou, P., Brouwers, J., \& Le, T.-A. (2014). Choosing a Qualitative Data Analysis Tool: A Comparison of NVivo and Leximancer. Annals of Leisure Research, 17(2), 218234. https://doi.org/10.1080/11745398.2014.902292

Stoltzfus, E. (2004). Citizen, Mother, Worker: Debating Public Responsibility for Child Care After the Second World War. North Carolina: UNC Press Books.

Tolbert, C. J., Mossberger, K., \& McNeal, R. (2008). Institutions, Policy Innovation, and EGovernment in the American States. Public Administration Review, 68(3), 549-563. https://doi.org/10.1111/j.1540-6210.2008.00890.x

Wang, Y., Hu, H., \& Yang, X. (2019). The Government R\&D Subsidies and China's Regional Innovation Output: Based on the Bayesian Model Averaging (BMA) Method. Chinese Management Studies, 14(2), 359-371. https://doi.org/10.1108/CMS-022019-0069

Weerakkody, V., \& Reddick, C. G. (2012). Public Sector Transformation through EGovernment: Routledge.

Wei, J., \& Liu, Y. (2015). Government Support and Firm Innovation Performance: Empirical Analysis of 343 Innovative Enterprises in China. Chinese Management Studies, 9(1), 38-55. https://doi.org/10.1108/CMS-01-2015-0018

Yang, S., Li, Z., \& Li, J. (2020). Fiscal Decentralization, Preference for Government Innovation and City Innovation: Evidence from China. Chinese Management Studies, 14(2), 391-409. https://doi.org/10.1108/CMS-12-2018-0778

Yoon, D. (2018). The Policy Research of Preliminary Feasibility Study For the Government R\&D Innovation Strategy. International Journal of Engineering Business Management, 10, 1-11. https://doi.org/10.1177\%2F1847979018778696 